\title{
COCONUT MARKETING: ISSUES FOR A THREATENED INDUSTRY
}

by

\author{
GEOFFREY BASTIN*
}

\section{SUMMARY}

The coconut industry is under pressure from low world oil-seed prices and the increased availability of palm kernels. This paper reviews market conditions in the lauric sub-sector, describes the marketing channels for copra and coconut oil, and sets out details of significant issues for the future. It concludes that the industry must take urgent steps to (a) improve the flow of market information, (b) develop cost saving means of production which lead to a range of items, and (c) investigate new markets for non-traditional products.

Up to the 1950s, copra was king in the oilseeds industry. As a premium oil bearing material it provided the lauric and myristic acids essential in a range of industrial applications. At the same time, coconut oil $(\mathrm{CNO})$ was a major ingredient in the edible sub-sector, a necessary part of margarine and shortening formulation.

Times have changed. Advances in petro-chemical engineering have limited the growth of industrial demand and offered cheap benzene substitutes to the detergent industry; on the edible side, the growth of the soybean and oil palm industries have kept the world more than adequately supplied with vegetable oils. From time to time world demand exceeds supply, but this is usually the result of adverse weather conditions, rather than any deliberate, price-related adjustments. Indeed, prices trending downwards have apparently stimulated productivity increases and shifts into lower cost oilseed crops.

Nowhere has this been more apparent than in the ofl palm industry, where growth of cultivation over the last twenty years has been phenomenal. The lauric oils sectur seems certain to absorb the greatest impact of this growth, since palm kernels, by-products of oil palm fruit bunch millings, are the main substitutes for copra as a source of lauric fatty acids.

Despite the enroachments of palm kernels and palm kernel oil (PKO), copra and coconut oil stiff dominate the lauric sector. PKO accounts for around 30\% of consumption, though in terms of international trade, the quantities of both oils are much closer. However, as palm oil production pushes towards 13 million tonnes by the year 2000 (from 6.5 million tonnes in 1985), the increased availability of kernels seems likely to reverse this situation. In these circumstances, the UN International Trade Centre in Goneva has estimated that the coconut industry has a "window" of five to ten years in which to radically change its approach to the market. It seems timely, therefore, to review existing conditions, and to set out some of the main issues to which the industry must address itself.

*Director, Oilseeds Research Landell Mills Commodities Studies London. 


\section{Production and Consumption.}

World output of copra is hkely to rise again from the level experienced in $1984 / 85$, but the very low level of prices for copra products suggests that production will continue to be below the average of 4.4 million tonnes for the 1980/81 to 1984/85 period (see Table 1). Trees have substantially recovered from the drought and typhoon damage which beset them in the 1982/83 season, so the potential for a surge in production clearly. exists. However, the sharp rise in prices which occurred as a result of the supply shortage - outturn fell by $20 \%$ in 1983/84 compared with the previous season, and prices rose by $46 \%$ to peak in April 1984 - switched demand in the edible sector away to alternative oils. Copra products, chiefly coconut oil, are thus having to buy their way back into a market which has become increasingly disfflusioned with erratic supplies- margarine manufacturers continue to use coconut oil, but in much smaller quantities and then only if the price is right.

Diagram 1 shows that in price terms, the lauric oils have performed less well than an aggregate index of other edible oils prices, such as soybean, palm and sunflowerseed. This does not mean that the laurics are less valuable on a dollar per tonne basis - reference to Diagram 2 will show that coconut oil has enjoyed a substantial premium on many occasions - but that the fall in the lauric oil price has been greater than that of competing oils. Given that copra and coconut oil (CNO) are costly to produce, the adverse effects of an oversupplied world market are likely to be felt more in this sector (and hence in the APCC region) than elsewhere.

Copra producers have understandably become disillusioned with the crop as values fall away. As revenues decrease, production is often pushed up to meet target incomes (a feature noted during the previous slump in 1981/82), but only up to a certain point. Thereafter, resources are shifted into other uses. On the basis of this analysis, supply prospects for 1985/86 are improved, by $7.4 \%$ to 4.2 million tonnes. Prices remain low, owing to wary edible demand. The outlook is for continued price volatility, greater vulnerability to substitutes, and an industry which, in the long-term, seems set to contract as higher cost producers shift to more profitable activities.

On a country-by-country basis, the Philippines produce $45 \%$ of the world's copra supplies of 4 mn tonnes. Until recently, almost none was exported, following a ban in September 1983 aimed at supporting the ailing domestic crushing industry which suffers from chronic over-capacity. The small quantities which were smuggled out reflect the difficulties which seem certain to limit any real recovery of the industry: copra production is the main agricultural activity in the Philippines, with the majority being undertaken by share-cropping smallholders who have few altemative sources of income. For this reason, any serious development of the industry relating to the pricing and marketing structure of copra has been neglected, the common view being that smallholders will continue to produce no matter what the price. The considerable research work which has been done, has focussed on developing new, hybird, high-yielding varieties of coconut palm; and huge financial resources have been poured into the primary and downstream processing sectors.

The result is that the Philippines is a world leader in agricultural science relating to coconut, and the major exporter of coconut oil and chernical. products such as lauric-based methyl esters. The $1985 / 1986$, production of these materials is expected to increase as further fatty acid production from

the newly commissioned Unichem plant becomes available. But the fluid political situation raises questions about the future viability of industrialisation which have yet to be resolved. The dominance of the defunct United Coconut Oil Mills conglomerate, until April 1985 the sole legal purchaser of copra domestically, has meant that producers have failed to, benefit from increased valueadded. Farm-gate prices substantially lower than world levels have provided few incentives to replant an ageing tree population with new, higher-yielding varieties. 
Table 1: Copra supply and demand balance

\begin{tabular}{|c|c|c|c|c|c|c|}
\hline $\begin{array}{l}\text { Production/ } \\
\text { Processing }\end{array}$ & $1980 / 81$ & $1981 / 82$ & $1982 / 83$ & $1983 / 84$ & $1984 / 85$ & $1985 / 86$ \\
\hline & & & \multicolumn{2}{|c|}{ ('000 tonnes) } & & \\
\hline $\begin{array}{l}\text { Opening stocks } \\
+\end{array}$ & 200.00 & 468.0 & 694.0 & 898.0 & 885.3 & 1059.3 \\
\hline Production & & & & & & \\
\hline Philippines & 2450.0 & 2500.0 & 2250.0 & 1710.0 & 1640.0 & 1700.0 \\
\hline Indonesia & 1040.0 & 950.0 & 1000.0 & 785.0 & 1040.0 & 1100.0 \\
\hline India & 372.0 & 376.0 & 385.0 & 345.0 & 365.0 & 370.0 \\
\hline Malaysia & 96.0 & 100.0 & 103.0 & 104.0 & 79.0 & 95.0 \\
\hline Other & 882.0 & 902.0 & 864.0 & 729.0 & 952.0 & 935.0 \\
\hline Total & 4840.0 & 4828.0 & 4602.0 & 3673.0 & 4076 & 4200.0 \\
\hline Crushing & & & & & & \\
\hline Philippines & 2150.0 & 2115.0 & 2040.0 & 1600.0 & 1515.0 & 1830.0 \\
\hline Indonesia & 1017.0 & 957.0 & 1010.0 & 888.0 & 1040.0 & 1062.0 \\
\hline India & 381.0 & 382.0 & 389.0 & 348.0 & 365.0 & 370.0 \\
\hline Malaysia & 92.0 & 104.0 & 102.0 & 71.7 & 73.0 & 88.0 \\
\hline Other & 932.0 & 1044.0 & 857.0 & 778.0 & 909.0 & 912.0 \\
\hline Total $=$ & 4572.0 & 4602.0 & 4398.0 & 3685.7 & 3902.0 & 4262.0 \\
\hline End stocks & 468.0 & 694.0 & 898.0 & 885.3 & 1059.3 & 997.3 \\
\hline
\end{tabular}

Source: Landell Mills Commodities Studies

Indonesia has a1w ays played a balancing role in the world copra and coconut oil markets, changing from exporter to importer depending on price movements and available supplies. The introduction of a "check" price for CNO exports by the Philippines in August 1985 (an example of the policy changes which have dogged the industry), which forbade the export of CNO under 23 cents/lb, presented the Indonesians with a heaven sent opportunity to establish a significant market share. Although coconut oil is the preferred Indonesian cooking oil, consumers have been persuaded to become more price conscious and to switch to palm oil when the world market offered advantageous terms to CNO exporters. Like the Philippines, Indonesia has been a traditional producer of copra, but the industry has developed at a slower pace, with more of an emphasis on cultivation techniques and the replacement of aged trees. From this point of view, Indonesia has a greater potential for increased. Production in 1985/86; thus new plantings will account for a jump in copra production to $1.1 \mathrm{mn}$ tons from 830,000 in 1984/85.

Much of this copra will. be processed at the village level into "klentik" or home-processed oil. This small-scale processing of the raw copra material allows the Indonesians considerable flexibility in market response. Village producers, operating at a low cost and input level, are able to- match CNO against Crude Palm Oil on the local market in a way wholly different from Filipino share-croppers. Thus in 1984/85, drawing on CNO reserves, Indonesia emerged onto the world market as an important supplier of coconut oil in order to enjoy premium prices while they lasted., domestic consumption moved to palm oil. 

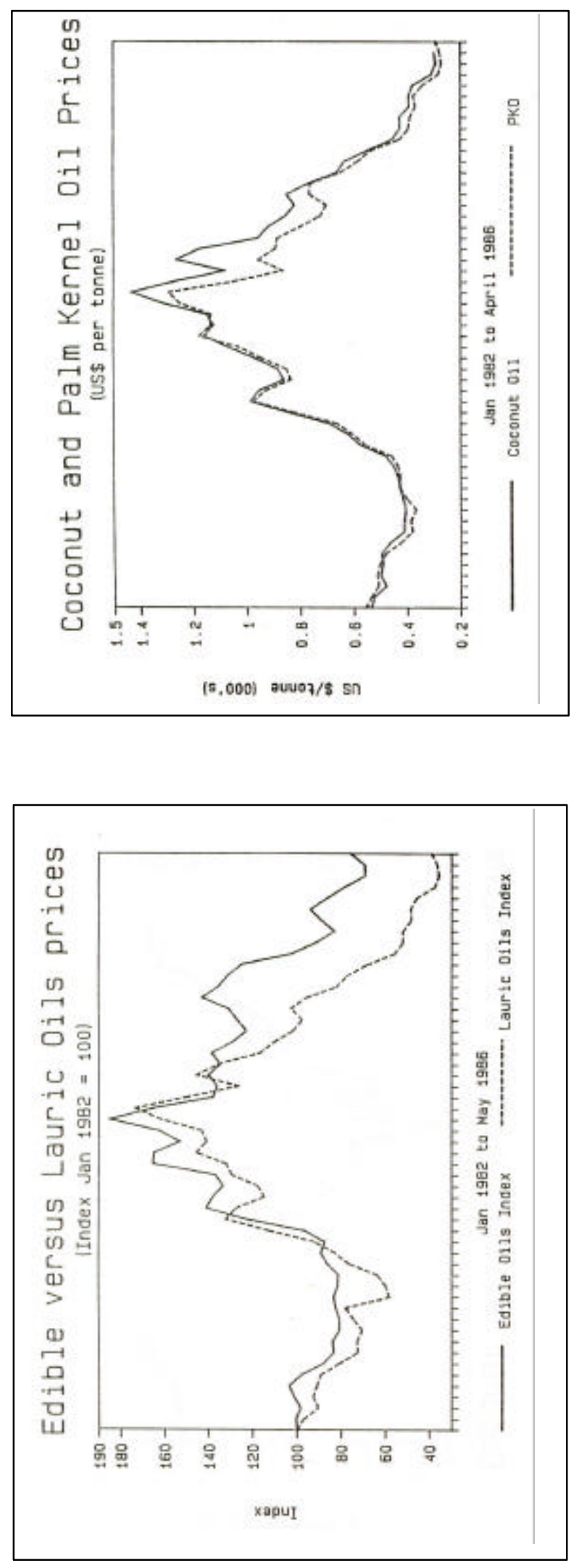
However, the prospect of the balance of export interest remaining with Indonesia cannot fill consumer with enthusiasm, at present Indonesian export policies are still unclear, so supply availabilities are not much more reliable than those of the Philippines. The Indonesian authorities have announced a limit on CPO exports of $10 \%$ of production, in order to assure sufficient domestic stocks, and to release $\mathrm{CNO}$ for export, they have also removed export duties on coconut oil. Nevertheless, Indonesian domestic prices remain substantially higher than world market prices, and unless some readjustment occurs, this may prove a disincentive to increased exports in 1985/86.

With the larger producers of copra concemed above all to process as much of the product domestically, countries such as Papua New Guinea and the Solomon Islands have become the major suppliers of copra to the remaining European millers. Recovery from the drought has been dramatic and record prices produced record copra receivals during the 1984/85 crop year. However, a high degree of price elasticity of supply indicates that with prices much lower, production in 1985/86 will be no more than in the previous year. Fortunately, most of the smaller island economies set aside a proportion of the revenues received during price hikes to stabilise farm prices in the troughs, but these sources of support are finite. The South Pacific countries depend heavily for foreign exchange earnings on coconut processing, but have at the same time high production costs. The burden on support funds is intense, and when the producer can no longpr receive his production costs, his enthusiasm for the crop Waries rapidly. The indications for 1985/86 are that price support will enable coconut farmers to cover cost and increase production to meet target incomes. But thereafter, assuming prices foflow previous cyclical patterns, support funds will come under pressure and marginal producers, will cease activity.

Considered in terms of the world oilseeds economy, copra supplies have become of minor concem to processors outside the Philippines and Indonesia. In Europe, copra crushing crashed by $56 \%$ in 1983, improved slightly in 1984, and was down again in 1985. Table 2 shows that some increase in total processing is foreseen in the 1985186 period, but that the greatest rise will be concentrated outside Europe. Coconut oil supplies are, of course, more important, but less so than hitherto. Continental margarine manufacturers continue to use small quantities of CNO in margarine, but, nevertheless, have been prepared to substitute with palm kernel oil as it became increasingly available at a discount.

Industrial users of lauric oils are much more restricted, since their only viable alternative is palm kernel oil which is produced in much smaller quantities than CNO. Nevertheless, as the technology to modify vegetable oil at the refining stage develops, lauric acid substitutes, principally derived from palm kernel oil, will increase their advantage. US consurners have been less comfortable with PKO, and in any event have utilised coconut oil almost exclusively for industrial purposes, where substitution is less easy. From this perspective it seems that the CNO market may swing progressively to North American destinations during 1985/86. However, it is unlikely that the major industrial consumers would. have neglected to advance research into viable alternatives, and a substantial move to PKO is foreseen. The ratio of CNO stocks to demand has risen substantially, to stand at its highest level since early 1984 . Viewed from the demand side, therefore, little pressure exists to raise prices.

The aggregate lauric oil market situation is summarised in Table 3. Production of both PKO and $\mathrm{CNO}$ has continued to rise, and, despite a generally downward trend in price, has failed to draw out sufficient demand to prevent the build up of stocks. Of greater concem is the consistent price advantage PKO has enjoyed against CNO. The prices of the respective oils move closely together, and it seems clear that in conditions of increasing kernel supply, a falling kernel oil price will drag CNO values down with it. 


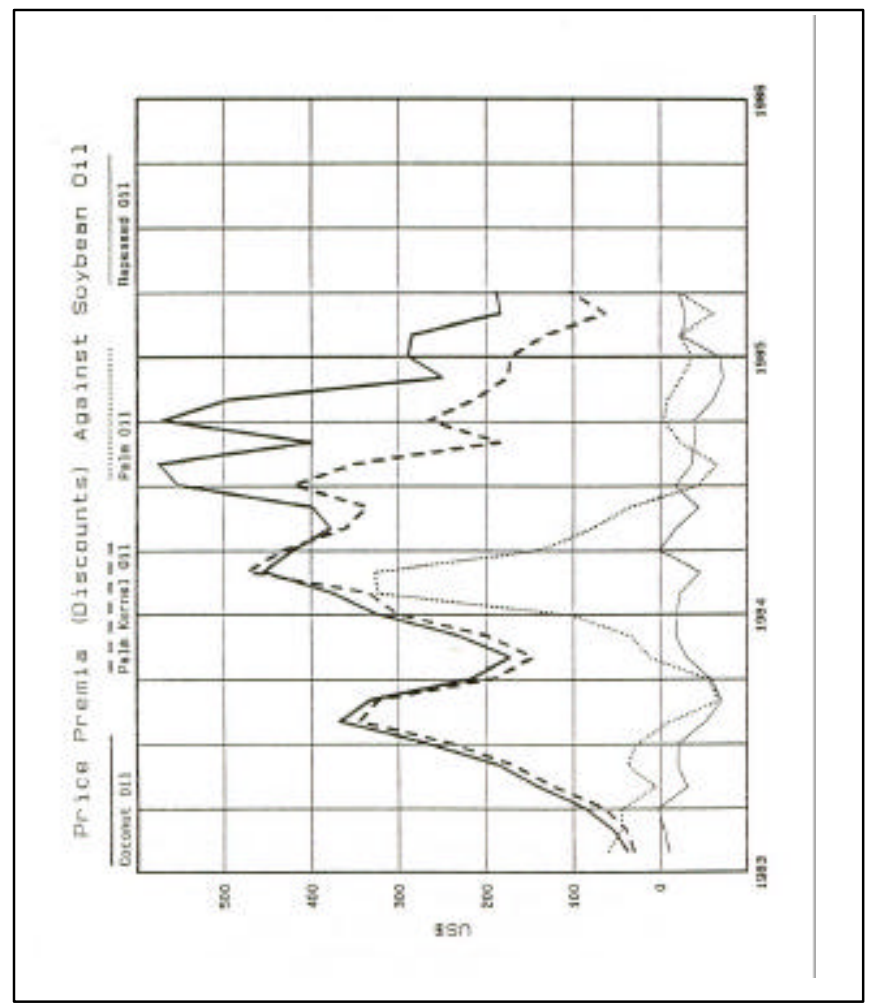

\section{Marketing Channels}

A feature of the coconut industry is that, although it cultivates the entire tree which is able to produce more than 70 products, the focus of the world oilseeds market is upon just two, CNO and copra cake. Of -these, by far the most important in the APCC region is coconut oil. Some member countries such as India and Sri Lanka have important coir sub-sectors, but these enter a quite different market.

This paper focuses upon marketing copra and CNO frour the Pacific and the South Seas Islands. There are two reasons for this : first, for the last three years, no copra has been officially allowed to be exported from the Philippines (although a considerable amount has slipped out illegally via Sabah on to the Singapore market), and it is important to set out some of the issues concerning intemational trade in the basic raw material; second, the Philippine coconut industry is cuffently undergoing re-evaluation which could lead to, considerable restructuring.

As far as the Indian sub-continent is concemed, the markets, are often domestic, and these also require a different approach from that adopted here.

Marketing Boards in the South Pacific countries sell copra to a limited number of companies world-wide. Sales are made on long-term contracts, based upon a fixed annual freight rate and an average pricing system. Purchasing organisations, mostly intemational trading companies, sell the copra to the crushing industry for processing to oil and cake.

This three-tiered industry structure has operated for many years, despite periodic chaflenges founded upon the existence of oligopsony (a very small number of purchasers) at the second tier. Economic theory would suggest that oligopsony leads to collusion, and a reduction of prices paid to producers. Critics have also questioned whether a second tier is necessary at all. 
Table 2: Coconut Oil Supply and Demand Balance

\begin{tabular}{|c|c|c|c|c|c|c|}
\hline $\begin{array}{l}\text { Production/ } \\
\text { Consumption }\end{array}$ & $1980 / 81$ & $1981 / 82$ & $1982 / 83$ & $1983 / 84$ & $1984 / 85$ & $1985 / 86$ \\
\hline \multicolumn{7}{|c|}{ ('000 tonnes) } \\
\hline $\begin{array}{c}\text { Op'ng stocks } \\
+\end{array}$ & 471.0 & 463.9 & 468.1 & 429.6 & 303.4 & 394.7 \\
\hline Philippines & 1376.0 & 1353.6 & 1305.6 & 1024.0 & 969.6 & 1171.2 \\
\hline$\%$ ? & & -1.6 & -3.5 & -21.6 & -5.3 & 20.8 \\
\hline Indonesia & 610.2 & 574.2 & 606.0 & 568.3 & 665.6 & 679.7 \\
\hline$\%$ ? & & -5.9 & 5.5 & -6.2 & 17.1 & 2.1 \\
\hline India & 236.2 & 236.8 & 241.2 & 215.8 & 226.3 & 229.4 \\
\hline Malaysia & 58.0 & 65.5 & 64.3 & 45.9 & 46.7 & 56.3 \\
\hline Other & 587.2 & 657.7 & 539.9 & 497.9 & 581.8 & 583.7 \\
\hline Total & 2867.5 & 2880.4 & 2758.9 & 2324.1 & 2501.8 & 2743.2 \\
\hline$\%$ ? & & 0.4 & -4.2 & -15.8 & 7.6 & 9.6 \\
\hline \multicolumn{7}{|l|}{ - } \\
\hline Consumption & & & & & & \\
\hline EEC & 527.7 & 557.7 & 479.4 & 402.5 & 326.4 & 400.0 \\
\hline$\%$ ? & & 5.7 & -14.0 & -16.0 & -18.9 & 22.5 \\
\hline Indonesia & 615.0 & 576.0 & 607.0 & 604.0 & 595.0 & 500.0 \\
\hline$\%$ ? & & -6.3 & 5.4 & -0.5 & -1.5 & -16.0 \\
\hline Total & 2874.6 & 2876.2 & 2797.4 & 2450.3 & 2410.5 & 2682.9 \\
\hline & & 0.1 & -2.7 & -12.4 & -1.6 & 11.3 \\
\hline$=$ & 4639 & 468.1 & 429.6 & 303.4 & 394.7 & 4550 \\
\hline $\begin{array}{l}\text { End stock } \\
\text { Prices } \$ / t\end{array}$ & $\begin{array}{l}463.9 \\
583.0\end{array}$ & $\begin{array}{l}400.1 \\
500.0\end{array}$ & $\begin{array}{l}429.6 \\
608.0\end{array}$ & $\begin{array}{r}303.4 \\
1123.0\end{array}$ & $\begin{array}{l}594.1 \\
764.0\end{array}$ & $\begin{array}{l}455.0 \\
568.1\end{array}$ \\
\hline $\begin{array}{l}\text { Prices } \$ / \mathrm{t} \\
\% ?\end{array}$ & & -14.2 & 21.6 & 84.7 & -32.0 & -25.6 \\
\hline
\end{tabular}

Source: Landell Mills Commodities Studies.

Note: "Consumption" calculated as residual disappearance and the symbol

“\% ?" indicates percentage change on the last period.

In fact, the presentation of the market in tenns of a collusive second tier seems rather unfair. No doubt there is scope for price-fixing, but since the copra price is derived from that of CNO and cake, and since these are determined by a free world market, in practice price fixing would be difficult. These issues are discussed in more detail in Sections 3 and 5 below.

Broadly speaking, there are four markets into which copra can be sold: to a local processor (the case in Papua New Guinea, Western Samoa and Fiji), to European traders who have long established links with the suppliers, to Japanese agents of the Fuji Oil mill, and into the "spot" market. Sales on the "spot" tend to be made to Singapore, or Korea, and by their nature are not subject to forward sales arrangements.

Shipping is usually negotiated by the Boards, so sales are c.i.f, although actual month-to-month arrangements tend to be made by the purchaser, at least as far as long-term contracts are concerned. Liner freight and charters are used, the former on the European routes and the latter in the Far East. 
Copra processing and oil extraction has become a relatively concentrated industry. Japan has one mill, PNG another, Western Samoa a third. Indonesia has several and a massive "village" scale industry. In Europe a theoretical crushing capacity of 430,000 tonnes exists, but it is likely that only

Table 3: Lauric Oil Supply and Demand Balance

\begin{tabular}{|c|c|c|c|c|c|c|}
\hline $\begin{array}{c}\text { Production/ } \\
\text { Consumption }\end{array}$ & $1980 / 81$ & $1981 / 82$ & $1982 / 83$ & $1983 / 84$ & $1984 / 85$ & $1985 / 86$ \\
\hline & \multicolumn{6}{|c|}{ ('000 tonnes) } \\
\hline Production & 3516.4 & 3594.5 & 3571.2 & 3125.6 & 3423.8 & 3773.2 \\
\hline $\begin{array}{r}\text { Consumption } \\
=\end{array}$ & 3540.1 & 3577.5 & 3623.7 & 3259.1 & 3299.0 & 3679.3 \\
\hline Change in stocks & -23.7 & 17.0 & -52.5 & -133.5 & 124.8 & 93.9 \\
\hline End stocks & 561.3 & 578.3 & 525.8 & 392.5 & 517.1 & 611.0 \\
\hline Price Index & \multicolumn{2}{|c|}{$($ Jan 1982=100) } & $\begin{array}{c}1982 \\
100\end{array}$ & $\begin{array}{l}1983 \\
97.5\end{array}$ & $\begin{array}{l}1984 \\
140.1\end{array}$ & $\begin{array}{l}1985 \\
73.6\end{array}$ \\
\hline $\begin{array}{l}\text { Average PKO } \\
\text { Price discount to } \\
\text { CNO (US\$/tonnes) }\end{array}$ & -21.0 & 4.0 & 18.0 & 82.0 & 92.0 & 168.1 \\
\hline
\end{tabular}

Source: Landell Mills Commodities Studies

Note: This table aggregates data on PKO and CNO

some 100,000 tonnes is currently utilised, with 6 mills out of the existing 10 "mothballed". Those which continue to crush, such as Karlshamn in Sweden, do so as an "insurance" against breaks in the supply of Phihppine CNO. The Philippines continues to dominate the industry, and, despite the break-up of the UNICOM monopoly, will no doubt continue to do so.

\section{Copra and Products Pricing}

From the processors, oil passes into a variety of end uses, but demand has latterly been derived from technical uses (e.g. in soap) rather than edible use in margarine. One of the problems confronting $\mathrm{CNO}$ is that when. the price is high, technical users; search for synthetic alternatives (e.g. linear alkyl benzene sulfortate), whereas when they are low, the oil must compete with freely available palm or soybean oil.

One of the difficulties about predicting CNO prices, therefore, is how to account for the twin influences of quite separate enduses. Put simply, the point at which CNO is dropped entirely in margarine formulations is an unknownp although we can say that technical usage is rather unresponsive to price, the absence of a real feel for the point at which demand switches is a major problem.

Another influence is that of the PKO price. The oils are near substitutes and reference to the diagram will show that the prices run closely together, PKO usually showing a slight discount. The important question here is which oil leads the lauric sector. Two years ago the answer would have been unhesitatingly CNO; now, with the amounts of each oil traded so similar, it is much more difficult to be so definite. The sensible coconut analyst will watch the palm oil and PKO market as closely as he does his own. 
At a less theoretical level, price reporting has been a subject for considerable discussion. CNO prices present few difficulties; the market is large and prices are reported by various agencies. However, copra price reporting, or more precisely, the use to which the existing system (satisfactory in itself) is put, is more problematic.

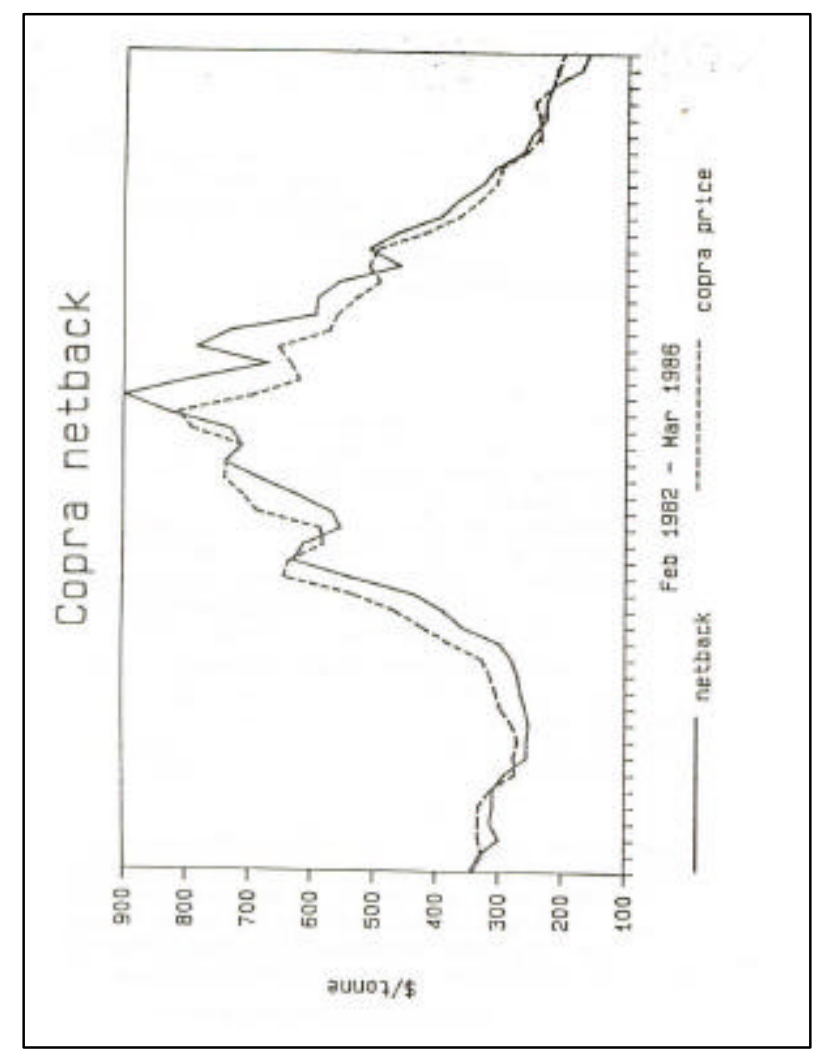

Most forward contracts use the FOSFA price for the previous month as the basis for trade, and this causes concern that actual market prices, as opposed to those reported, are not adequately reflected. Prices are reported by FOSFA on the basis of telephoned reports by a small number of European buyers and sellers. The possibility of collusion exists, although it must be clearly stated that no evidence whatsoever exists that it occurs; indeed close examination suggests the opposite. Nevertheless, the mere possibility has led some to suggest alternative ways of arriving at a reference price.

One way is to "netback" from the price of coconut oil and meal. A "netback price" for copra is calculated on the basis of product realisations, minus extraction, freight and other costs. In this way a "fair" reference price can be calculated for trade negotiations. Providing agreement can be reached on the cost element, the netback price can even be projected forward to give some indication of what future prices for the raw material are likely to be. Such a method, if properly utilised could have major advantages for the operation of producer price stabilisation funds.

The netback provides a useful check on the FOSFA report. The calculation presented in Diagram 3, indicates that, in fact, the two prices run closely together. The slight divergence between the two curves, with the netback first running below, and then above the copra price, is a result of the way this rather simple calculation is lagged: the FOSFA price takes a backward look, whereas the netback looks forward from existing product prices to what the price of copra should be in the next period. This difficulty can be easily overcome. 


\section{Producer Pricing and Stabilisation}

This is an enormously complicated issue, worthy of a paper in its own right. There are two things which can be said, however, first, as Diagram 4 shows, producer price stabilisation is certainly worthwhile, if it can be achieved without driving the actual price so low that benefits are completely lost. The diagram provid $\sim \mathrm{s}$ monthly daia on changes in world and Philippine (buying station) prices. It will be seen that Filipino coconut farmers prices fluctuated more wildly than world prices, and on some occasions bore no relation at all to the world price. Economic theory would suggest that this would provide a severe disincentive to coconut cultivation and investment in the industry; evidence from the Philippines shows this to be the case.

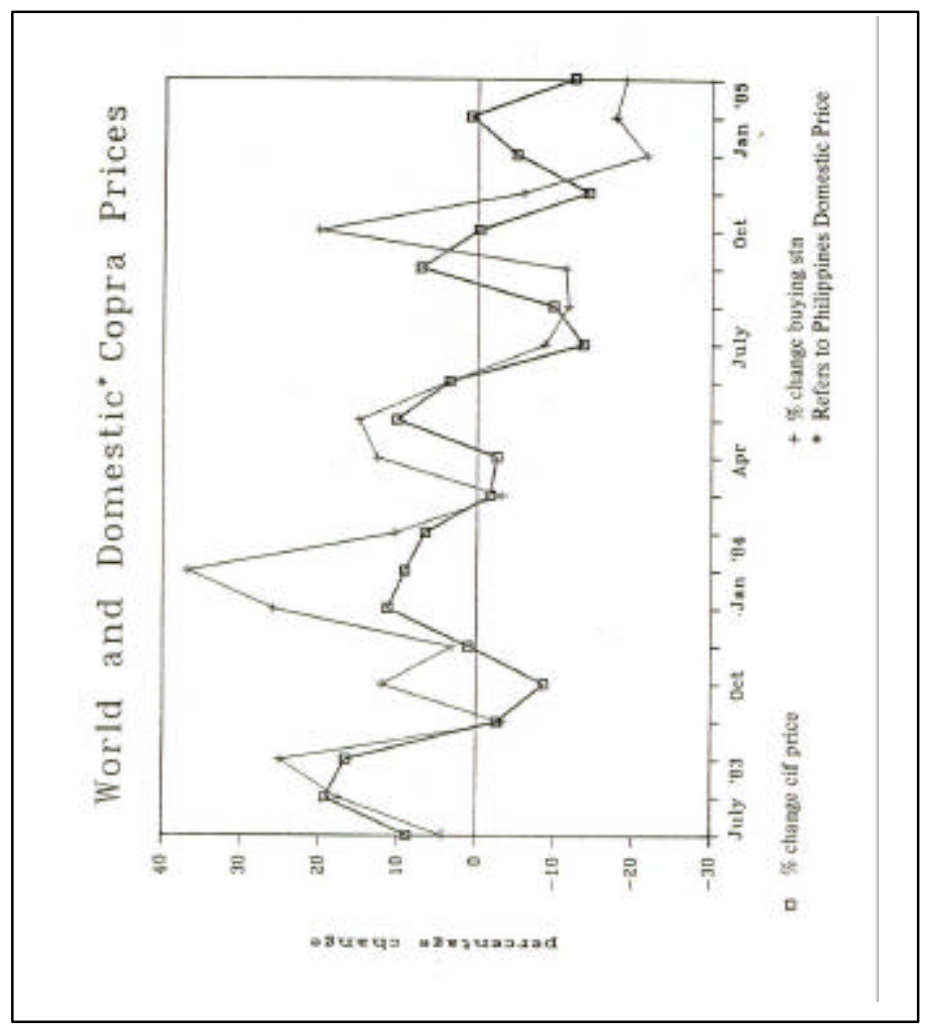

The second issue regarding stabilisation, is that whatever system is introduced, it must not be regarded by the industry as a price support mechanism. Equally, central govemment must not utilise stabilisation funds as financial reserves for purposes other than those intended. A stabilisation fund must, therefore, incorporate an accurate price reporting mechanism, based on accurate market information, together with a fair means of adjustment to changes in world prices. Unfortunately, in many cases, neither of these criteria have been applied.

\section{Risk Management}

Stabilising farmers prices and incomes (separate objectives), should be part of an overall strategy to manage the risks which clearly arise at all stages of coconut production and processing. In this regard, the question of oligopsony requires further discussion. 
There is no doubt that the present marketing system does deny producers some freedom of action, both domestically, where farmers sell to marketing boards, and internationally, where the 1 second tier' of traders operate. However, the costs of this loss must be offset against the benefits of minimising risk.

Physical commodity markets differ from other consumer markets in that demand is not continuous: at any time it can be positive, negative or zero. Traders, able to adopt 'long' (bought) or 5 short' (sold) positions, carry the difference and balance the equation between supply and demand.

Copra trading, by the very nature of long shipment periods and the requirement that most marketing boards are long in the material, involves systematic risk. The risk involves holding large supplies of copra at a time when the market price is falling, thus risking substantial losses on the trading account. International traders face the same risks, but with some advantages: communications and information are the lifeline of markets where prices can fluctuate $\$ 50$ to $\$ 100 /$ tonne in a matter of hours, and most coconut producers are far from the CNO and copra markets in Japan, London, Rotterdam and New York. Equally traders work several markets, laying off risks in one, against those in another ('hedging'). Coconut producers cannot do this, since they tend to trade in only one, or two commodities.

Another aspect is the risks attached to shipping, meeting deadlines and documentation. Practical arrangements are handled by the second tier which raises Bills of Lading, arranges freight and makes complicated 'book' adjustments so that buyers requirements are met. For example, a day's delay in loading can result in a Bill of Lading dated October rather than September. This could result in a lower price or a refusal by a buyer on the grounds of default. Traders can overcome these difficulties.

The point should not be laboured. Undoubtedly as communications improve and the flow of information to producers grows, much can be done to handle risk at source. Markets can be targetted and much more use made of 'spot' sales. In this regard, the information project to be undertaken by the APCC should go a considerable way to assisting producers manage their own risks, rather than 'pay' someone else to provide this service for them.

\section{Conclusions}

It follows from these comments that the most useful short-term actions which can be taken by coconut producers, are to improve information systerns and trading techniques. Much can be done to raise fanners welfare by making gains 'at the margin' by negotiating better freight rates and by 'beating' the market - or at least ensuring that an average of world prices is received by farmers over a long enough period. Experience in the Philippines has shown that farmers can survive periods of poor prices, but they will not survive low prices and uncertainty regarding the future.

Stable prices will allow the major replanting projects to go ahead. The long-term future for the coconut industry no doubt relies on lowering production costs and increasing labour productivity. However, the success of these prograrnmes ultimately depend upon the market.

This paper has shown that the market for traditional products is threatened by substitute oils (PKO in particular) and a general oversupply of oilseeds world-wide. Acknowledging this, the International Trade Centre in Geneva has combined with APCC and a number of donor countries to promote, the diversification of the industry into non-traditional products. Diversifying into, new

markets is another way of managing risk, so the project makes good sense. It will depend on more market information and an integrated approach to industrialisation, using conventional copra extraction processes and new technology such as the 'wet process'. If the programme is successful the 
industry will. survive; if not, then. coconut could become a subsistence crop only, leaving the developing countries of the APCC region to search elsewhere for exportable commodities.

\section{Bibliography}

APCC, "Cocomunity" Newsletter

Bastin G 'Copra Price Stabilisation in Papua New Guinea: A Review of Policy and Administration' CMB Papers September 1983

Bastin G Copra' in "World Commodity Outlook 1986: Food, Feedstuffs and Beverages' Economist Publications October 1985

Coulter H 'Proposals for a New Stabilisation Scheme' CMB Papers 1984

'Export Crops Quarterly Review', Department of Primary Industry, Papua New Guinea, 1979 to 1983

Landell Mills Commodities Studies Ltd., "Oils and Oilseeds" Monthly Bulletin, London and New York.

Landell Mills Commodities Studies Ltd, 'A Review of Copra and Coconut Oil Marketing', London, January 1983

Shepherd A 'Copra Marketing in Papua New Guinea', Department of Primary Industry, Port Moresby, 1978

United Coconut Authority of the Philippines 'Weekly Bulletin' 